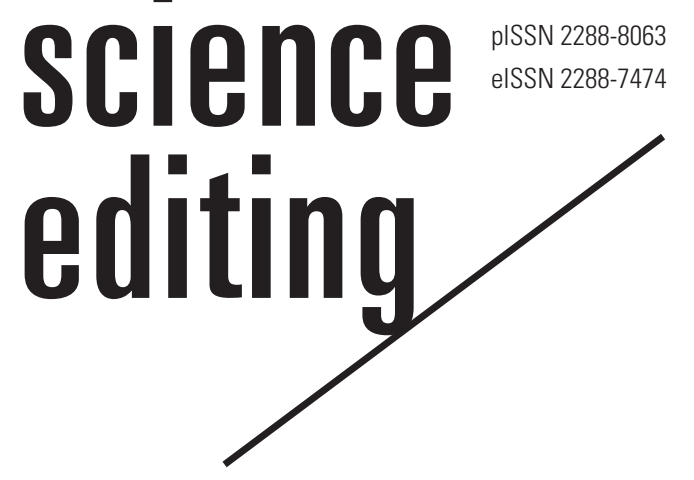

\title{
Current status of Indonesian journals in the field of Islamic economics and finance
}

\author{
Luqman Hakim Handoko, ${ }^{1,2}$
}

${ }^{1}$ School of Islamic Economics (STEI) SEBI, Depok, Indonesia; ${ }^{2}$ Kulliyyah of Economics and Management Science, International Islamic University Malaysia (IIUM), Kuala Lumpur, Malaysia

\begin{abstract}
This study aimed to explore the status of Indonesian journals in the discipline of Islamic economics and finance. In the last two decades, the emergence of Islamic economic journals was striking. As of November 2019, the Science and Technology Index (SINTA) contained 60 journals on Islamic economics, banking and finance, accounting, management and business, and philanthropy. To explore these journals, a content analysis was conducted using data in the SINTA database. Most of the Islamic economics and finance journals were in SINTA level 4 (out of 6). Only 8 journals were ranked in SINTA level 2, and none were in SINTA level 1. Based on these results, additional efforts are needed to improve journal quality. Moreover, many journals have not been indexed in SINTA, which might have good quality. The author suggests that further efforts be made to include Islamic economics and finance journals in other abstracting and indexing databases, such as the Directory of Open Access Journals, Moraref, and Garuda.
\end{abstract}

Keywords

Abstracting and indexing; Access to information; Indonesia; Periodicals as a topic; Bibliographic databases

Received: December 24, 2019

Accepted: January 11,2020

Correspondence to

Luqman Hakim Handoko

lukman.hakim.handoko@sebi.ac.id

ORCID

Luqman Hakim Handoko

https://orcid.org/0000-0003-0973-6607

\section{Introduction}

The emergence of the discipline of Islamic economics was accompanied by universities offering Islamic economics programs, and journal publications are needed to supply the market demands. In Indonesia, according to data retrieved from the database of higher education (Pangkalan Data Pendidikan Tinggi, https://pddikti.ristekdikti.go.id), there are nearly 900 departments of Islamic economics and finance in various degrees. In addition, there is a regulation that mandates the publication of articles by graduate students, lecturers, associate professors, and professors. These aspects of the academic environment have increased the need for qualified journals that focus on Islamic economics. However, an outstanding question is whether this high demand for journals has been accompanied by an increase in the number of high- 
quality journals. For this reason, existing journals in this field must be assessed.

There are many ways to assess the quality of journals. Indexing is a common way to trace and identify the quality of a journal. Common indices used in the social sciences include Scopus, the Social Science Citation Index, and the Emerging Sources Citation Index [1]. According to a decision of the Ministry of Higher Education and Technology of Indonesia, journals indexed in these databases are categorized as highly reputable journals. In contrast, if a journal is indexed in the Directory of Open Access Journals (DOAJ), it is treated as a journal that meets the minimum requirements $[2,3]$.

Some studies have assessed the quality of journals in the discipline of Islamic economics and finance globally. For example, Arshad [4] analyzed 25 journals in the field of Islamic economics and finance around the world, and found that concerns remained regarding credible journals and the lack of visibility. Nonetheless, some of the journals, such as the Journal of King Abdulaziz University, Islamic Economics, and the International Journal of Islamic and Middle Eastern Finance and Management were of sufficiently high quality to be indexed in Scopus. More recently, Shafiq [1] investigated 73 journals in the field of Islamic economics and finance, and found that only eight journals were listed in Scopus, Social Science Citation Index, or Emerging Sources Citation Index. Most of these journals were from Indonesia, but none of the Indonesian journals was indexed in Scopus.

Therefore, this study was conducted to analyze Indonesian journals in the discipline of Islamic economics and finance. A thorough knowledge of the current state of Indonesian journals in this field may serve as a trigger for authors, publishers, colleges or universities, and any other related parties to further enhance their respective roles to strengthen Islamic economics and finance journals.

The Science and Technology Index (SINTA) was introduced in 2016 by the Director-General of Strengthening Research and Development of the Ministry of Research Technology and Higher Education of the Republic of Indonesia, with the participation of professionals from various organizations [5]. The SINTA database can be accessed through the address http://sinta.ristekdikti.go.id, and its purpose is to evaluate lecturers, study programs, institutions, and journals, as well as to serve as an independent index in Indonesia. Indonesian journals are ranked from SINTA level 1 (highest) to 6 (lowest).

\section{Methods}

To explore and describe the quality of journals, a simple quantitative content analysis was performed in this study. Data on
Islamic economics and finance journals were retrieved from http://sinta2.ristekdikti.go.id/journals. The first step in the search process was to find journals with keywords related to Islamic economics (Suppl. 1). The search was conducted in November 2019. Next, journals in the "economy" category were further searched. Data were collected on the year of publication, type of publication, language, and publication fee.

\section{Results}

Sixty journals were identified as Islamic economics and finance journals (Suppl. 2). The details of these journals can be found in Suppl. 2. Based on the data gathered, Islamic economics and finance journals only emerged within the last two decades. As shown in Fig. 1, the oldest journal was launched in 2004. Fig. 1 also shows that the number of these journals has increased rapidly, especially in the last 5 years. More than 30 journals were established by various institutions, and the period of 2015-2016 accounted for the highest number of new journals (12 and 10 journals, respectively).

The overwhelming majority of the journals $(n=57,95 \%)$ published on a semi-annual basis, while two journals (3\%) published on monthly basis, and one (2\%) published three issues a year (Fig. 2). As shown in Fig. 3, the Indonesian Islamic economics and finance journals had four language policies: Indonesian only (27); English only (9); both Indonesian and English (23); and Indonesian, English, and Arabic (1).

In Indonesia, all journals are typically open access, which means that researchers can access and download articles published on the journal website. However, it does not mean that it is free for researchers to submit to and publish manuscripts in those journals. Some journals charge a submission fee, an article processing charge, or a fee for fast-track review. Of the 60 journals related to Islamic economics and finance, 51 $(85 \%)$ were free of charge, while nine (15\%) required article processing charges. These charges ranged from 100,000 (7.2 US dollars) to $1,000,000$ Indonesian rupiah (72 US dollars).

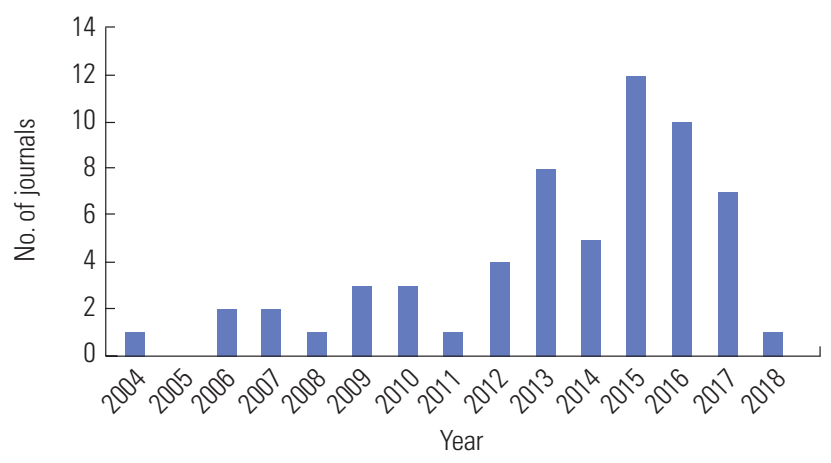

Fig. 1. Annual number of new journals published. 


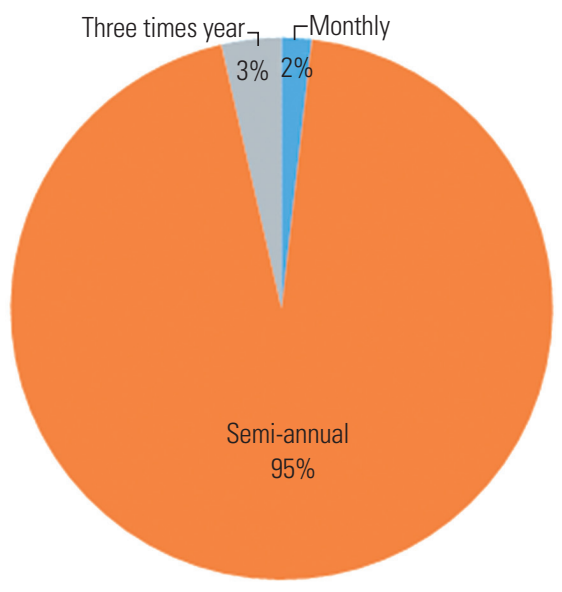

Fig. 2. Distribution of journals by frequency of publication.

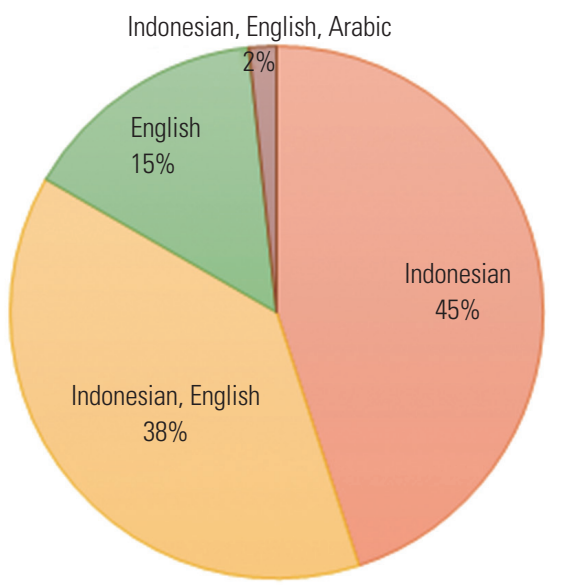

Fig. 3. Language policies of the journals.

Based on the data gathered from SINTA, there were 278 journals in the field of economics, and 60 of them were in the field of Islamic economics and finance. None of the Islamic economics and finance journals were in SINTA level 1, and none of these journals were indexed in highly reputable databases such as Web of Science and Scopus. The highest ranking was SINTA level 2, which included only eight (14\%) journals. Most of the Islamic economics and finance journals $(\mathrm{n}=31,52 \%)$ were in SINTA level 4 , followed by SINTA level $3(\mathrm{n}=17,28 \%)$. The remaining journals were in SINTA level 5 and 6, each of which contained two (3\%) journals (Fig. 4).

However, according to the journal webpages, most of these journals had been indexed in Garuda (http://garuda.ristekdikti.go.id/journal), Moraref (https://moraref.kemenag.go.id/ archives/journal), Crossref, Google Scholar, and DOAJ. Some of the journals were indexed in 15 or more indexes, such as Al-Iqtishad: Jurnal Ilmu Ekonomi Syariah (Journal of Islamic Economics), Economica: Jurnal Ekonomi Islam, Iqtishadia: Jur-

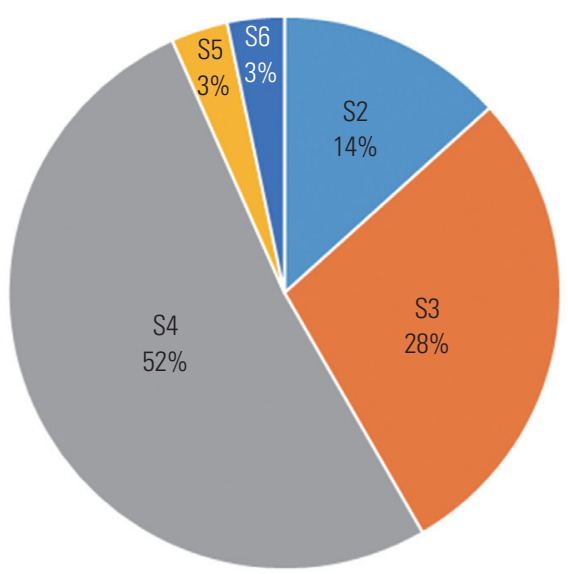

Fig. 4. Distribution of journals by Science and Technology Index level.

nal Ekonomi dan Perbankan Syariah, Al-Tijary: Jurnal Ekonomi dan Bisnis Islam, Shirkah Journal of Economics and Business, and An-Nisbah: Jurnal Ekonomi Syariah.

\section{Conclusion}

As shown in the above discussion, it is necessary to evaluate the research quality of Islamic economics and finance journals. For researchers, such an evaluation helps to determine where they should publish their articles, while for journal publishers, such findings provide valuable insights into how they can evaluate and improve the quality of their journals. The results showed none of the journals were in SINTA level 1 , and only eight of the 60 identified journals were in SINTA level 2. Most of the journals were in SINTA level 4, followed by SINTA level 3, and relatively few journals were in SINTA level 5 and 6.

An inherent limitation of this study is that it only focused on journals indexed in SINTA. As a result, many journals were not included in this study, even if they were indexed in Crossref, DOAJ, Garuda, and Moraref. It could be the journals that have not been indexed at SINTA have better quality. Nonetheless, the results of this study indicate that additional efforts are needed to improve journal quality. The author suggests that further efforts be made to include Islamic economics and finance journals in other abstracting and indexing databases, such as DOAJ, Moraref, and Garuda.

\section{Conflict of Interest}

No potential conflict of interest relevant to this article was reported. 


\section{Supplementary Material}

Supplementary file is available from: https://doi.org/10.6087/ kcse.191.

Suppl. 1. Keywords for Islamic economics and finance

Suppl. 2. List of Indonesian journals in the field of Islamic economics and finance indexed at Science and Technology Index

\section{References}

1. Shafiq A. A review of journals and publishing houses in the field of Islamic economics and finance (Vol. IKAM reports 8). Istanbul: Research Center for Islamic Economics; 2019.

2. Lukman, Ahmadi SS, Manalu W, Hidayat DS. A guideline for scientific publications [Internet]. Jakarta: Kementerian Riset, Teknologi, dan Pendidikan Tinggi Direktorat Jenderal Penguatan Riset dan Pengembangan; 2017 [cited 2019 Dec 21]. Available from https://risbang.ristekdikti. go.id

3. Ahmar AS, Kurniasih N, Irawan DE, et al. Lecturers' understanding on indexing databases of SINTA, DOAJ, Google Scholar, SCOPUS, and Web of Science: a study of Indonesians. J Phys Conf Ser 2018:954;012026. https://doi. org/10.1088/1742-6596/954/1/012026

4. Arshad MN. An assessment of journal quality in the discipline of Islamic economics. Islam Econ Stud 2016;24:95114. http://iesjournal.org/english/Docs/195.pdf

5. Kemenristekdikti. Sinta: About [Internet]. Jakarta: Kemenristekdikti [cited 2019 Dec 21]. Available from http:// sinta2.ristekdikti.go.id/about 